\title{
Consumer Purchasing Behaviour and Neuromarketing in The Context of Gender Differences
}

\section{Robert STEFKO, Anna TOMKOVA, Jana KOVALOVA and Ivana ONDRIJOVA}

University of Presov in Presov, Faculty of management, Slovakia

Correspondence should be addressed to: Ivana ONDRIJOVA; ivana.ondrijova@unipo.sk

Received date: 16 October 2020; Accepted date:3 February 2021; Published date: 9 June 2021

Academic Editor: Magdalena Zubiel-Kasprowicz

Copyright (C) 2021. Robert STEFKO, Anna TOMKOVA, Jana KOVALOVA and Ivana ONDRIJOVA. Distributed under Creative Commons Attribution 4.0 International CC-BY 4.0

\begin{abstract}
The paper, in the theoretical part, deals with the issue of neuromarketing and gender differences in the context of shopping behavior. The main goal is to identify statistically significant differences in the evaluation of consumer shopping behavior and neuromarketing in the context of gender equality. The research sample consisted of 204 respondents, of whom, 126 were men and 78 were women aged 18 to 59 years with an average age of 33.69 years. Respondents' data were obtained by occasional sampling. The data needed for the analysis were obtained through the authors' questionnaire, which was the primary source of data. Two research hypotheses were established for the paper. The obtained data were processed and interpreted at the level of descriptive statistics. At the level of induction statistics, the MannWhitney U test was used. The results were processed by mathematical-statistical methods in IBM Statistics SPPS 22.00. The results of the analysis confirmed the existence of statistically significant differences between male and female consumers when evaluating shopping behavior and neuromarketing.
\end{abstract}

Keywords: Gender differences, Neuromarketing, Purchasing behaviour.

\section{Neuromarketing}

Since the 1970s, studies that deal with the principles of brain function have started to appear. Young (2002) states that twenty years have passed since the first ideas of using and measuring brain activity, in the context of consumer behavior, arose. This

Cite this Article as: Robert STEFKO, Anna TOMKOVA, Jana KOVALOVA and Ivana ONDRIJOVA (2021), "Consumer Purchasing Behaviour and Neuromarketing in The Context of Gender Differences", Journal of Marketing Research and Case Studies, Vol. 2021 (2021), Article ID 321466, DOI: 10.5171/2021.321466 
concept was developed by psychologists at Harvard University in 1990. In 1996, the neuromarketing research by Shizgalo and Conover was carried out. In the research, there were combined neuroscience and mathematic theories that can make human behavior predictable. Gerald Zaltman professor of Harvard Business School who is thought as the "father of neuromarketing" in 1999 used FMRI method for brain observation. The word Neuromarketing was coined by Ale Smidts in 2002. The first scientific research in neuromarketing was made by a neuroscience professor of Baylor College of Medicine Read Montague in 2003. Worldwide companies as Coca-cola, Ford, or Google invested a big amount of funding to marketing at that time; however, results of researches were kept as confidential from the general public.

In this context, it is appropriate to refer to Nobel Laureate Francis Crick's statement, that the idea that all human feelings, thoughts and actions, even consciousness itself, are just the products of a neural activity in the brain. According to Morin (2011), neuromarketing is a field that bridges the study of consumer behavior and neuroscience. It is a modern and developing area with great potential for application to functional areas of marketing. It arises after merging concepts of neurology, psychology, human neurophysiology, and neurochemistry areas. Vysekalová (2011) states that neuromarketing connects knowledge of neuropsychology, cognitive psychology, and neuroscience in the neuromarketing environment. Daugherty and Hoffman (2017) state that marketing uses theories, ideas and approaches from the several disciplines (thinking, anthropology, sociology, etymology, neuroscience, biology, finance or arithmetic). Researchers in the field of neuromarketing are examining the human brain and nervous system to better understand the impact of marketing by measuring users' direct and indirect neurological processes. Morin (2011) states that neuromarketing is to marketing what neuropsychology is to psychology. While neuropsychology studies the relationship between the brain and human cognitive and psychological functions, neuromarketing promotes the value of looking at consumer behavior from a brain perspective.

Neuromarketing deals with designing marketing materials to evoke specific neurological reactions that trigger emotions or responses that are linked to purchasing (Gotter, 2019). Neuromarketing suspects that emotional basics influence decisions about products purchase (Badoc and BayleTourtoulou, 2014). Limbeck (2012) underlines the fact that purchase decision arises in the brain part called the limbic system, which is involved in behavioral and emotional reactions. Fournier (2018) adds that the limbic system is responsible for endorphins production, hormone levels, body temperature, and motor functions. Limbic system function was accidentally discovered by James Olds and Peter Milner (1954) during the experiment with electric stimulation of rats' brains which indicated "the brain reward system". These claims are supported by several psychological theories and researches in neuromarketing and neuropsychology fields (Sahakian, Gottwald, 2018; Georges et al., 2014).

Neuromarketing offers cutting edge methods for directly probing minds without requiring demanding cognitive or conscious participation (Morin, 2011). The field of neuromarketing analyses the human brain to predict and even potentially manipulate consumer behavior and decision making. The aim of neuromarketing is to combine neuroscience methods with neuromarketing theories to reveal the real, even out of sight, influence of marketing on consumer beahvior (Lim 2018). Tomková and Ondrijová (2018) infer that the aim of neuromarketing is to get information about consumers' brain activity during the influence of marketing stimuli, while its advantage, unlike the questionnaire survey, is that the results are not influenced by a consumer's prejudice or a choice to reveal real feelings, emotions, values and 
attitudes. Fortová (2015) claims that neuromarketing studies consumer reactions to marketing stimuli via monitoring brain activity. Harrell (2019) states that neuromarketing deals with the measurement of physiological and neural signals. The main goals is to investigate customers' motivations, preferences, and decisions, which can help inform creative advertising, product development, pricing, and other marketing areas. The aim is to find out how consumer decision-making is affected and what part of the brain is activated at the moment of decision-making. For example, it uses the following medical technologies: magnetic resonance imaging (fMRI), electroencephalography (EEG), etc. (Kozel, 2006). It can be concluded that this field brings new research methods with the potential to reveal still hidden information in the human mind.

Why does the neuromarketing cause ethical concerns? While neuromarketing has farreaching use in practice, it is important to deal with the matter ethically. Neuromarketing's problem with the principle of ethics comes from the fact that researchers can unconsciously cross the line of privacy, which violates consumer autonomy protection (Ondrijová, Tomková, 2017). Findings that come from the research could be damaged or used against the participants. Murphy et al. (2008) state that the privacy of individuals joined in neuroscience researches, taking place in medical institutions, is usually protected by the law. However, if neuroscience research is conducted for commercial purposes, then the protection of law is ineffective and privacy provision depends on the moral values of the researchers. The year 2012 was important for ethics from a neuromarketing perspective, when The Neuromarketing Science and Business Association, based in the Netherlands, approved a code of ethics, which came from the need to unify the rules of neuromarketing research, as many companies followed different standards. Harvard Review of Psychiatry study also demonstrates that the world's top neuromarketing companies provide very little information about their ethical standards (Morin, 2011).

A significant role in this field is played by consumers, who often do not know that they are part of the research or are affected by various neuromarketing tools. This is a reason why it is necessary to find a compromise between neuromarketing research, consumer protection, and maintaining ethical standards. Ducu (2016) states that neuromarketing research has a very practical goal: to inform effective marketing strategies and advertisement campaigns. On the other hand, there is a growing need to develop a code of ethics for the technologies involved in the neuromarketing research, and one for the business that takes the applications of neuromarketing research into consideration.

\section{Gender Differences}

Despite the well-known idea that men and women react to marketing stimuli differently, it is important to keep them under review. Due to more objective neuromarketing, we have a better opportunity to understand gender differences that lead to more accurate and personalized targeting and elimination of deficiencies (Vecchiato et al., 2014). Gender is a major factor that affects consumer purchasing behavior. Birknerová, Frankovský, Zbihlejová and Parová (2017) explain gender in socio-structural, interpersonal, and individual level. Men and women's brains are diametrically opposed to the structural and behavioral levels. These differences are formed from birth, last their whole lives, and influence attitudes and behaviors that affect their shopping behavior and consumer decisions. Women and men have different behaviors in decision making while shopping. The reason for these differences is in their upbringing and socialization, which later influence their attitudes, behaviors, perceptions, motivations, or values (Lakshmi, Aparanjini and Lahari, 2017). Hyde (2016) states that 
for understanding the psychological and gender differences, it is important to know individuals' education experiences, culture gender stereotypes, gender equality, and biosocial interaction. Jäncke (2018) states that gender differences are shaped by experience, education, culture, or a combination of these.

Hyde (2016) underlines the fact that in the matter of emotions, empathy, moral judgment and social behavior, differences between men and women are insignificant, or even disappear during the study of bigger samples or use of objective tools (except for those that a person exhibits about herself or himself). Results of questionnaire surveys can indicate non relevant results for as much as typical gender stereotypes and social expectations exist in the culture context (Ellemers, 2018; Williams and Dempsey, 2014; Christov-Moore et al., 2014; Derntl, Finkelmeyer, Eickhoff et al., 2010) with which men and women naturally identify themselves. Uva, Freitas and Paiva's (2015) research was focused on the study of gender and TV advertisements using electroencephalography. In this neuromarketing research, 10 men and 10 women participated, and their nervous activity during watching a video was recorded by electroencephalography (EEG). However, statistically significant differences between males and females were identified for all the electrodes. There were also identified differences in brain frequencies and activity of brain areas related to emotions, mainly of anterior cingulate cortex (ACC) which has been higher for men than for women. Men usually have better depth perception since they have a bigger pariental lobe. It is also the reason why they prefer pictures over reading. Due to the bigger amygdala, men are more aggressive than women. Female brains have a larger prefrontal cortex, which impacts emotions and how they're regulated. That is the reason why emotions are the most effective way to speak to them. Females' brains also allow for more intuitive reasoning, and the part of the brain responsible for worrying is larger.
Thanks to the larger corpus callosum, they are able to multi-task and organize their thinking. They also have a bigger hippocampus; that is the reason why their level of nuance in emotional details is much greater (Adelson-Yan, 2013).

There exist a number of studies that confirm different purchasing behaviours in the context of gender perspective. The research by Mitchell and Walsh (2006) shows that women are more perfectionist than men. Gender differences were also studied by Birknerová and Frankovský (2014), who, in their research, focused on managers' work. They identified statistically significant differences between emotional intelligence aspects between men and women. Men had higher scores in aspects as emotional control, self-motivation, stress management, low impulsivity level, assertiveness, adaptation, and relationships.

There is an interesting research carried out by Puccinelli (2013), who emphasizes that colors linked with shopping have a significant impact on men more than on women. Men associate red color with saving, and it has a positive effect on them during shopping. Also, when prices were highlighted with this color, men's perception of savings increased, unlike other colors. While this color made women skeptical. Women associated black color with saving. Another part of his research was focused on price information, where women exhibit better memory for price information and deeper processing of information than men.

The authors of this paper also agree with Beverland's (2006) findings where he emphasized the impact of music on the customer during shopping. The choice of the appropriate music and its appropriate volume led to the reinforcing of the brand, the pleasure of customers, and the attraction of new customers. However, quiet music gave them the unwanted feeling that they should communicate with the vendors, while louder music influenced the overall impression. Therefore, choosing inappropriate music can 
reduce the time spent by customers in the store, it can even make them leave, and subsequently avoid the store.

Daimler Chrysler company in Ulm researched which vehicles are the most attractive for men. Researchers showed respondents, at an average age of 31,66 pictures of different cars - 22 sports cars, 22 sedans and 22 small cars. The study was carried out using an fMRI. Sports cars have illuminated the area of the brain associated with reward and power much more than other models. Among the sports cars that had the strongest reactions to the brain were: Ferrari 360 Modena, BMW Z8 and Mercedes. Walter, a psychiatrist at the Ulm University Hospital who was involved in the study, found that sports cars do not only look more attractive to men but also demonstrate success, wealth and dominance (Wells, 2003).

On the other hand, women got higher scores in aspects like empathy, emotion expressing, and emotional appreciation. In the matter of emotional intelligence, men had higher scores in self-control and sociability, which indicates that they have healthy control over their desires, as well as good regulation of pressure and stress, and they are focused on social relationships and social influence. Women can better perceive and express emotions for keeping close relationships.

\section{Research}

Following the theoretical elaboration of the issue of neuromarketing and gender differences, the research focuses on identifying statistically significant gender differences in the assessment of Consumer purchasing behavior and Neuromarketing. This research was carried out via authors' questionnaire.

\section{Research Sample}

The research sample consisted of 204 respondents, of whom 126 were men and 78 were women aged between 18 and 59 years, with an average age of 33.69 years
$(S D=12,422)$. Data from respondents were obtained through occasional selection.

\section{Research Methodology}

The main objective of the paper is to identify the differences in the assessment of consumer purchasing behaviour and neuromarketing in the context of gender. For this contribution, the following research hypotheses were established:

H1: We assume that there are statistically significant differences in the assessment of the Consumer purchasing behaviour between men and women.

H2: We assume that there are statistically significant differences in the assessment of the Neuromarketing between men and women.

The data needed for the analysis were obtained through the questionnaire of the authors, which was the primary source of the data. The questionnaire was divided into three parts: The first part consists of statements that focus on the Consumer purchasing behaviour (items 1-10). The second part consists of statements that focus on the Neuromarketing and Ethics in it (items 10-20). The third part contained closed-ended categorization questions needed to classify respondents by age and gender.

The research participants were to respond, on a scale from 1 to 4 , to what extent they agree with the given statement $1=$ definitely no, $2=$ rather no than yes, 3 = rather yes than no, 4 = definitely yes). The data obtained were processed and interpreted at the level of descriptive statistics. At the level of inductive statistics, the Mann-Whitney U test was used, which is suitable for analyzing the data available to us and does not require a normal distribution. The results were processed by the mathematical-statistical methods in IBM Statistics SPPS 22.00. 


\section{Results and Discussion}

Based on the Mann-Whitney U test, it was found that there are statistically significant differences in assessing the 8 items of the questionnaire between men and women.
Table 1 shows the results of testing the hypothesis which examines the existence of differences between men and women in the assessment of Consumer purchasing behaviour and Neuromarketing.

Table 1: Statistically significant gender differences in the assessment of Consumer purchasing behaviour and Neuromarketing

\begin{tabular}{|l|c|c|c|c|c|c|c|c|}
\hline & $\mathrm{Q} 3$ & $\mathrm{Q} 4$ & $\mathrm{Q} 8$ & $\mathrm{Q} 12$ & $\mathrm{Q} 14$ & $\mathrm{Q} 18$ & $\mathrm{Q} 19$ & $\mathrm{Q} 20$ \\
\hline $\begin{array}{l}\text { Mann- } \\
\text { Whitney } \\
\mathrm{U}\end{array}$ & 3490,00 & 3522,00 & 3646,50 & 3798,50 & 3690,50 & 3472,00 & 3532,00 & 3728,00 \\
\hline $\begin{array}{l}\text { Wilcoxon } \\
\mathrm{W}\end{array}$ & $\begin{array}{c}10993,0 \\
0\end{array}$ & 11025,00 & 11027,50 & 11179,50 & 11193,50 & 10975,00 & 10913,00 & 11109,00 \\
\hline $\mathrm{Z}$ & $-3,179$ & $-2,966$ & $-2,711$ & $-2,289$ & $-2,710$ & $-3,083$ & $-2,958$ & $-2,384$ \\
\hline $\begin{array}{l}\text { Sig. } \\
(2 \text {-tailed })\end{array}$ &, 001 &, 003 &, 007 &, 022 &, 007 &, 002 &, 003 &, 017 \\
\hline
\end{tabular}

(Source: own processing)

The existence of statistically significant differences confirms the results in Table 2.

Table 2: Comparisons of the assessment of Consumer purchasing behaviour and Neuromarketing between men and women

\begin{tabular}{|l|l|c|c|c|c|}
\hline \multicolumn{2}{|c|}{ Gender } & $\begin{array}{c}\text { Mean } \\
\text { Rank }\end{array}$ & Median & Mean & $\begin{array}{c}\text { Standard } \\
\text { deviation }\end{array}$ \\
\hline $\begin{array}{l}\text { Q3_Product color is } \\
\text { important for me }\end{array}$ & Female & 115,68 & 3,00 & 2,82 &, 942 \\
\cline { 2 - 6 } & Male & 90,11 & 2,00 & 2,36 &, 980 \\
\hline $\begin{array}{l}\text { Q4_If something grabs my } \\
\text { attention, I have to buy it. }\end{array}$ & Female & 114,16 & 3,00 & 2,45 &, 929 \\
\cline { 2 - 6 } & Male & 90,37 & 2,00 & 2,05 &, 969 \\
\hline $\begin{array}{l}\text { Q8_Social networks have an } \\
\text { impact on my product } \\
\text { choice. }\end{array}$ & Female & 112,64 & 2,00 & 2,31 &, 877 \\
\cline { 2 - 6 } & Male & 91,14 & 2,00 & 1,97 &, 884 \\
\hline $\begin{array}{l}\text { Q12_I would be willing to } \\
\text { participate in } \\
\text { neuromarketing research. }\end{array}$ & Female & 110,67 & 3,00 & 2,60 &, 877 \\
\cline { 2 - 6 } $\begin{array}{l}\text { Q14_It is possible to } \\
\text { influence a customer to buy } \\
\text { a specific product by using } \\
\text { neuromarketing tools. }\end{array}$ & Male & 92,39 & 2,00 & 2,29 &, 987 \\
\cline { 2 - 6 } & Male & 91,75 & 3,00 & 2,80 &, 624 \\
\hline $\begin{array}{l}\text { Q18_Neuromarketing ethics } \\
\text { are essential. }\end{array}$ & Female & 113,71 & 4,00 & 3,51 &, 682 \\
\cline { 2 - 6 } & Male & 89,96 & 3,00 & 3,07 &, 972 \\
\hline Q19_It is necessary to & Female & 113,03 & 4,00 & 3,46 &, 701 \\
\hline
\end{tabular}

Robert STEFKO, Anna TOMKOVA, Jana KOVALOVA and Ivana ONDRIJOVA, Journal of Marketing Research and Case Studies, DOI: 10.5171/2021.321466 


\begin{tabular}{|l|l|c|c|c|c|}
\hline $\begin{array}{l}\text { lreate legislation strictly } \\
\text { following ethics. }\end{array}$ & Male & 90,19 & 3,00 & 3,04 &, 978 \\
\hline $\begin{array}{l}\text { Q20_Neuromarketing basic } \\
\text { education for customers, } \\
\begin{array}{l}\text { where they can get new } \\
\text { information, should be } \\
\text { instituted. }\end{array}\end{array}$ & Female & 110,45 & 3,00 & 3,08 &, 829 \\
\cline { 2 - 6 } & Male & 91,81 & 3,00 & 2,78 &, 871 \\
\hline
\end{tabular}

(Source: own processing)

Statistically significant differences in the individual Consumer purchasing behaviour components were recorded in items 3, 4 and 8.

In item no. 3 "Product color is important for $m e "$, higher scores were made by females whose average answers were 2.82, so they were closer to the answer "rather yes", unlike males $(2,36)$. Statistically significant differences were also found in item no. 4 "If something grabs my attention, I have to buy $i t$ ". In this case, again, females had higher scores (2.45), unlike males (2, 05). Females ranged on a scale between "rather no than yes" and "rather yes than no", while males were closer to the answer "rather no than yes". In the last item of the assessment of Consumer purchasing behaviour no. 8 "Social networks have an impact on my product choice", females again scored slightly higher (2.31), against males (1.97). In both cases, they were on the same side of the scale in answering "rather no than yes". Moreover, statistically significant differences in the individual Neuromarketing components were recorded in items 12, 14, 18, 19 and 20 . Even in this case, in all the assessed items, females scored slightly higher than males.

In item no. 12 "I would be willing to participate in neuromarketing research", females got higher scores $(2,60)$, unlike males $(2,29)$. It is concluded that females would be willing to participate in neuromarketing research, considering their answers "rather yes than no"; unlike males whose answer was "rather no than yes". Even though, in item no. 14 "It is possible to influence a customer to buy a specific product by using neuromarketing tools", females scored $(3,11)$ higher than males $(2$, 80). In both cases, they were in the same part of the scale and approach to the answer "rather yes than no".

In item no. 18 "Neuromarketing ethics are essential", females scored 3, 51, and males 3, 07 . Although this difference is not significant, females expressed their degree of agreement with this statement. Also in item no. 19 "It is necessary to create legislation strictly following ethics", the identified differencies are not significant; however, females with a score of 3, 46 would demand following ethical principles more than males with a score of 3,04 .

In both cases, they were on the same side of the agreement of the rated scale.

In the last item of the assessment of Neuromarketing no. 20 "Neuromarketing basic education for costumers, where they can get new information, should be instituted", females $(3,08)$ scored higher than males $(2,78)$. In both cases, they were on the same side of the agreement of the rated scale and preffered the answer "rather yes than no".

The authors of this paper can confirm the existence of statistically significant differences in the evaluation of consumer purchase behaviour between men and women in favour of women. It is deduced that men are more sensitive to scents, delightful music, cleanliness, lighting, and the interior design of a store. They care more about product brand and packaging design. They are also more sensitive to the product price. On the other hand, women care more 
about the color of the product, and they are more likely to be influenced by social networks when choosing a product. It has also been observed that the existence of statistically significant differences in the evaluation of neuromarketing is in favour of women. It is concluded that women would be more initiative in neuromarketing investigation. Women believe that it is possible to influence a customer's product choice by neuromarketing tools. They also emphasize ethics in neuromarketing, and declare that, in their opinion, the state needs to create legislation that would be followed. Women emphasize the implementation of neuromarketing basics teaching that can enrich customers' knowledge about the issue.

Based on the Mann-Whitney U test, it was found that there are statistically significant differences in assessing the Consumer purchasing behaviour between men and women. Therefore, the hypothesis $\mathrm{H} 1$ has been confirmed, and H2was also confirmed, because it was found that there are statistically significant differences in the assessment of the Neuromarketing between men and women. The authors of this paper can't follow only the information that respondents provide about themselves in quantitative and qualitative research, because sometimes they mean something different than they mention or they do not state their final decision.

The brain, even unconsciously, constantly calculates the most advantageous decision for it at the moment. A difference between what people think and what they say is caused by one of the neural network algorithms that have proven to be the most useful for life (Tomková, Ondrijová, 2018).

Since neuromarketing companies are reluctant to share their information, researches are limited. Krugrman (1971) claimed that reading and speaking are located in the right hemisphere, while visual perception is located solely in the left hemisphere. So, newspaper is appropriate for the right hemisphere and television for the left one. The other important findings were related to other functions and their classification, such as the emotion experience which is situated on the right side, while the cognitive functions of perception are on the left side. High levels of involvement of the individual activated the right hemisphere, and conversely, low levels activated the left hemisphere. In the context of television advertising, the brain uses recognition, while in the context of print ads, it uses recall. He also described some differences between families with the lower and higher economic position. Svetlík (2012) states that his theories have some deficiencies as his statements were not supported by any empiric research, and therefore, they have a large number of opponents, which include not only scientists, but also people who are directly involved in marketing. In 1996, Shizgal and Conover have conducted the research in neuromarketing field where they combined neuroscience and mathematical theories in the belief that they can be applied in social sciences to predict behavior (De Sousa, 2018).

This research is focused on gender differences in the assessment of neuromarketing attributes. Based on MannWhitney test, it was found out that there are statistically significant differences in the assessment of consumer purchasing behavior between men and women, in favor of women. It was also found out that in favor of women, there are statistically significant gender differences in neuromarketing assessment. In general, it is concluded that men are more sensitive to scents, pleasant music, cleanliness, lighting, and the interior design of the store. They care more about the brand and design of the product packaging. They are also more sensitive to the price of the product. On the other hand, women care more about the color of the product, they are more likely to be influenced in their product choice by social networks and they give importance to ethics in neuromarketing.

Hsu a Cheng (2018) examined whether gender influences brain activation associated with word-of-mouth communications. The 
fMRI results showed that males treat product quality perception as a constant. On the other hand, females' results suggest a dynamic representation for product quality perception (i.e. not a constant). Vecchiato et al. (2014) performed an experiment in order to investigate cognitive and emotional changes of cerebral activity evaluated by neurophysiologic indices during the observation of TV commercials. They showed that there are results suggesting that it is possible to differentiate the communication according to the gender. Cuesta, Nino and Martinez (2018) analyzed the mechanisms of action of 3 psychophysiological variables widely used in this field: eye-tracking, galvanic skin response and facial emotion. They found some gender differences in terms of visual attention.

The paper aimed to identify and specify the differences in the assessment of neuromarketing between men and women. This aim was achieved by the questionnaire method, and results were processed by a statistical program. The aim of the paper was supported by the theoretical framework in which the authors have been focused on marketing, business and neuromarketing. Neuromarketing is answering questions related to emotions that are important for people during making purchase decisions. These findings are used to improve psychology and marketing efficiency. They are applied mainly for product design, promotion and advertising improvement, store design and improvement of customer experiences in all spheres.

\section{Acknowledgment}

This paper is supported by the grant VEGA $1 / 0807 / 19$ Research on the determinants of trading behavior and marketing effects in the area of neuromarketing and the relation to neuro-linguistic programming.

\section{References}

- $\quad$ Adelson-Yan, J. (2013) 'Neuromarketing $\&$ the Science of Marketing to Women vs. Men,' [Online] [Retrieved 17.05.2020] Available:

https://www.askingsmarterquestions.c om/neuromarketing-the-science-ofmarketing-to-women-vs-men

- Beverland. M. et al. (2006) 'In-store music and consumer-brand relationships: Relational transformation following experiences of (mis)fit,' [Online], [Retrieved 08.05.2020] Available: https://www.sciencedirect.com/scienc e/article/abs/pii/S0148296306000981

- Badoc, M., Bayle-Tourtoulou, A. S. and Georges, P. M. (2014) Neuromarketing in action: how to talk and sell to the brain, London: Kogan Page.

- Birknerová, Z., Frankovský, M. (2014) Rodové diferencie v prejavoch sociálnej, emocionálnej inteligencie a machiavellizmu v manažérskej práci, Prešov: Radix, spol. s r. o.

- Birknerová, Z., Frankovský, M., Zbihlejová, L. and Parová, V. (2017). 'Gender differences in perception of advertising in the context of expectations of advertising,' Journal of applied economic sciences, 12(6), 17511758.

- Cuesta, U., Niño, J. I., and MartínezMartínez, L. (2018) 'Neuromarketing: Analysis of Packaging Using Gsr, EyeTracking and Facial Expression,' Papper presented at The European Conference on Media, Communication \& Film.

- Daugherty, T. and Hoffman, E. (2017) 'Neuromarketing: understanding the application of neuroscientific methods within marketing research,' Thomas, A.R., Pop, N.A., Iorga, A.M., Ducu, C. (Eds), Ethics and Neuromarketing: Implications for Market Research and Business Practice, New York: Springer, 5-30. 
- Derntl, B., Finkelmeyer, A., Eickhoff, S. et al. (2010) 'Multidimensional assessment of empathic abilities: neural correlates and gender differences,' Psychoneuroendocrinology, 35(1):67-82.

- De Sousa, J. C. (2018) Neuromarketing and Big Data Analytics for Strategic Consumer Engagement, Hershey.

- Ducu, C. (2016) 'Topoi in Neuromarketing Ethics,' Ethics and Neuromarketing, 31-64.

- Ellemers, N. (2018) 'Gender Stereotypes,' Annual Review of Psychology, 69, 275-298.

- Fořtová, J. (2015) 'Neuromarketing $v$ kostce: co všechno potřebujete vědět. Markething, [Online], [Retrieved 08.01.2015] Available: http://www.markething.cz/neuromark eting-v-kostce-co-vsechno-potrebujetevedet

- Gotter, A. (2019) 'Neuromarketing 101: How Neuroscience Affects Customers' Buying Behaviors,' [Online], [Retrieved 05.06.2020] Available: https://www.singlegrain.com/digitalmarketing/neuromarketing-101-howneuroscience-affects-customers-buyingbehaviors/

- Harrell, E. (2019). 'Neuromarketing: What You Need to Know,' [Online], [Retrieved 08.05.2020] Available: https://hbr.org/2019/01/neuromarket ing-what-you-need-to-know

- Hsu, M. Y.-T. and Cheng, J. M.-S. (2018) 'fMRI neuromarketing and consumer learning theory,' European Journal of Marketing, 52(1/2), 199-223.

- Hyde, J. S. (2016) 'Sex and cognition: gender and cognitive functions,' Curr Opin Neurobiol, 38:53-6.

- Christov-Moore, L., Simpson, E.A., Coudé, G., et al. (2014) 'Empathy: gender effects in brain and behavior,' Neurosci Biobehav Rev., 46, 4:604-27.

- Jäncke, L. (2018) 'Sex/gender differences in cognition, neurophysiology, and neuroanatomy,' US National Library of Medicine National Institutes of Health
- $\quad$ Kozel, R. (2006) Moderní marketingový výzkum: nové trendy, kvantitativní a kvalitativní metody a techniky, průběh a organizace, aplikace v praxi, přínosy a možnosti, Praha: Grada Publishing.

- Krugman, H.E. (1971) 'Brain wave measures of media involvement,' Journal of Advertising Research. 11(1), [Online], [Retrieved 10.12.2019] Available:

https://www.researchgate.net/publicat ion/322685580_Measuring_consumer_ neural_activation_to_differentiate_cogni tive_processing_of_advertising_Revisitin g_Krugman

- Lim, W.M. (2018) 'Demystifying neuromarketing,' J. Bus. Res. 91, 205220.

- Limbeck, M. (2012) Jak myslí špičkový obchodník. Praha: Grada.

- Mitchell, V.W. and Walsh, G. (2006) 'Gender differences in German consumer decision making styles,' Journal of Consumer Behaviour. 3(4), 331-346.

- Murphy, E. et al. (2008). 'Neuroethics of neuromarketing,' Journal of Consumer behavior, 7, 293-302.

- Morin, Ch. (2011) 'Neuromarketing: The new science of consumer behavior,' Society, 48(2), 131-135.

- Ondrijová, I. and Tomková, A. (2017) 'Neuromarketing a jeho etické aspekty v spotrebitel'skom správaní,' Journal of Global Sciences. 2 (1).

- Puccinelli, N. and Rajesh Ch. (2013) 'Are Men Seduced by Red? The Effect of Red Versus Black Prices on Price Perceptions,' [Online], [Retrieved 08.05.2020] Available:

https://www.sciencedirect.com/scienc e/article/abs/pii/S0022435913000031

- Sahakian, J.B. and Gottwald, J. (2018) Mohou neurovedci číst naše myšlenky?, Praha: Portal s.r.o.

- Svetlík, J. (2012) o podstate reklamy, Bratislava: Eurokódex, s.r.o.

- Tomková, A. and Ondrijová, I. (2018) 'Podstata a prínosy neuroekonómie,' Journal of global science, 3 (2). 
- Uva, T., Lucas, C. and Paiva, T. (2015) 'Neuroscience technologies in marketing: a study of gender and TV advertisements using electroencephalography,' International Journal of Technology Marketing, 10 (4), $362-380$.

- Lakshmi, V., Aparanjini, D. and Lahari, G. (2017) 'Impact of Gender on Consumer Purchasing Behaviour,' IOSR Journal of Business and Management, 19(8), 3336.

- Vecchiato, G. et al. (2014) 'Neurophysiological Tools to Investigate Consumer's Gender Differences during the Observation of TV Commercials,' Computational and Mathematical Methods in Medicine, 1-12.
- Vysekalová, J. et al. (2011) Chování zákazníka. Praha: Grada Publishing, a.s.

- Wells, M. (2003) 'Search of the Buy Button,' [Online], [Retrieved 15.04.2020] Available: https://www.forbes.com/forbes/2003/ 0901/062.html\#460488ee7353

- Williams J. C. and Dempsey, R. (2014) 'What Works for Women at Work: Four Patterns Working Women Need to Know,' New York: NYU Press

- Young, Ch. (2002) 'Brain Waves, Picture Sorts, and Branding Moments,' Journal of Advertising Research, 42 (4), 42-53. 